\title{
Negation patterns in Bengali
}

\author{
HANNE-RUTH THOMPSON \\ School of Oriental and African Studies
}

\section{Introduction}

Negation is a challenging chapter in Bengali grammar which has so far attracted remarkably little attention. Bengali negation is complex: there are no negative pronouns and adverbs but there are negative verbs, and negation can be linked to tense. In this article I offer an overview of Bengali negation patterns as they exist in modern Standard Bengali, without going into great detail on etymological morphology or, for that matter, a complex debate on logical aspects or truth conditions.

Of all the negational features in Bengali, the status of $n i$ as a tensed negative has attracted the most attention, but findings are far from conclusive and some very basic questions have remained unasked. A relatively recent essay by Gillian Ramchand 'Two types of negation in Bengali' (unpublished, 2001) gives a semantic analysis of the two forms $n a$ and $n i$ and offers some interesting new perspectives.

Suniti Kumar Chatterji's tentative claim that $n i$ is a variation of nai, and his uncertain stance on the role of the incomplete verb ach-in the formation of perfect tense forms has been generally accepted but not examined. Chatterji deals with negative verbs in one short paragraph in the 'Additions and corrections' to his 1,300-page opus The Origin and Development of the Bengali Language, and makes no meaningful distinctions between the different forms. Anderson, in his useful, if dated, Manual of the Bengali Language (Cambridge, 1920) devotes all of six lines to the negative in a paragraph entitled 'The negative verb', which I quote here in full:

Negation is expressed by putting na after the finite verb and before the nonfinite verb, with one remarkable exception. It is not usual to say korlam na. The proper negative of the preterite is kori nai. This applies to all preterites except chilam. It is permissible to say chilam na. (p. 17).

Much of this is controversial for modern Bengali and I hope to show, among other things, how peacefully korlam na and korini (the equivalent of Anderson's kori nai) can co-exist.

One thing that is immediately apparent in Bengali is that there are no negative adverbs or pronouns. How do Bengalis say 'never'? They don't - and this simple fact alone constitutes a significant difference between negation in Bengali and negation in English. Whereas in English we can say 'Nobody came', in Bengali we can only say keu ase ni, which literally means 'anyone did not come'. The negative element is moved from word-level to sentencelevel and it is logical to start with the tentative assumption that in Bengali all negation happens on the syntactic level. We do not encounter the ambiguity of double negatives such as 'I won't have none of that', 'I didn't say nothing' because negative adverbs and pronouns like nothing, nobody, none, nowhere or never do not exist.

There are double negatives of a different kind, however, involving lexical negation. This is a fairly simple morphological feature consisting of negative affixes and does not really concern us here. But for the sake of a well-rounded picture, these affixes should at least be mentioned. Most Bengali prefixes have two allophones, one for preceding vowels and one for preceding consonants. Milne (1913) gives a complex listing of Bengali affixes and their very varied 
semantic impact. Of those that can be classed as having a negating quality $o$ (on) is the most common. Bengali morphology is dealt with in detail in many grammar text books, so here are just a few examples. Nouns (including verbal nouns) and adjectives take the same prefixes; suffixes are word-class specific. What I have given as the 'nearest root word' is in most cases not the basic form, but it is sufficient to show the building blocks (see Table 1).

Below are some sentences containing more than one negative element. These are mostly combinations of a negatively prefixed noun or adjective with a sentence negation, but occasionally (sentence ii) two negatively prefixed elements come together. The rhetoric element in these sentences is equivalent to English structures such as 'it is not impossible...', 'it is not unheard of...'. All these sentences are from Otol joler dike by Prophullo Ray.

(i) nijer odhikarer sīma kotodūr poryonto țana, seța tar ojana noy ${ }^{1}$ He was not unaware of how far he could stretch the limits of his privileges.

(ii) tãr modhye emon ek probol byktitvo royeche, ya omanyo kora osombhob

Apart from this she had such a strong personality that it was impossible to ignore it.

Table 1.

\begin{tabular}{|c|c|c|c|c|}
\hline \multirow{2}{*}{$\begin{array}{l}\text { prefix } o \text { (before } \\
\text { consonants) }\end{array}$} & \multicolumn{2}{|c|}{ Nearest root word } & \multicolumn{2}{|c|}{ Affixed negative form } \\
\hline & kșomota & power & okșom & powerless \\
\hline & sombhob & possible & osombhob & impossible \\
\hline & moron & death & omor & immortal \\
\hline & pūrṇo & full & opūrṇo & incomplete \\
\hline & sahajyo & help & osohai & helpless \\
\hline & gonona & $\begin{array}{l}\text { counting, } \\
\text { reckoning }\end{array}$ & ogonyo & $\begin{array}{l}\text { uncountable, } \\
\text { innumerable }\end{array}$ \\
\hline \multirow[t]{3}{*}{$\begin{array}{l}\text { prefix on } \\
\text { (before vowels) }\end{array}$} & onto & end, termination & ononto & $\begin{array}{l}\text { endless, } \\
\text { infinite }\end{array}$ \\
\hline & upoyukto & suitable & onupoyukto & unsuitable \\
\hline & odhikar & right & onodhikar & interference \\
\hline \multirow[t]{3}{*}{ prefix nir } & olos & lazy & nirolos & $\begin{array}{l}\text { unceasing, } \\
\text { untiring }\end{array}$ \\
\hline & $a s ́ a$ & hope & niraśa & despair \\
\hline & ohonkkar & pride & nirohonkkarī & $\begin{array}{l}\text { unassuming, } \\
\text { humble }\end{array}$ \\
\hline \multirow[t]{3}{*}{ suffix $h \bar{i} n$ (adj.) } & $\begin{array}{l}\text { polok } \\
\text { uddeśyo }\end{array}$ & $\begin{array}{l}\text { wink, twinkling } \\
\text { purpose }\end{array}$ & $\begin{array}{l}\text { polokhīn } \\
\text { uddeśohīn }\end{array}$ & $\begin{array}{l}\text { unblinking } \\
\text { purposeless, } \\
\text { aimless }\end{array}$ \\
\hline & ortho & meaning & orthohin & meaningless \\
\hline & svartho & self-interest & svarthohin & unselfish \\
\hline
\end{tabular}

${ }^{1}$ The transliteration used in this paper differs from the Standard Sanskritic transliteration in the following areas: (1) The Bengali inherent vowel is given as o, not as a. I consider this a correction of a longstanding problem. The inherent vowel in Bengali is pronounced o or ō but never a. (2) য, য় and yophola $\zeta$ are all given as y. (3) Bisorgo : is given as h-this corresponds to the Library of Congress use. (4) No distinction is made between donto $t(\bullet)$ and khondo $t(९)$ - both are given as $\mathrm{t}$. 
(iii) yodi onekdin kachakachi thaka yeto ōke pheranō osombhob hoto na If he had managed to stay close, it would not have been impossible to bring her back.

(iv) gari calate calate pronobeś onoboroto kotha bole yacchilen thiki, tobe ei ghōraghurita nichok uddeśohin bhromonnoy

While he was driving, Pranobesh kept on talking incessantly, but this travelling around was not just an aimless journey.

The numbered example sentences in this article are taken from the Dhaka literary journal kali ō kolom (Ink and Pen) Vol 7, August 2004, and from a range of contemporary novels. They are cited as primary literature. My term 'real' or 'live' examples excludes all sentences from grammars, courses or text books which serve to demonstrate particular structures.

\section{A comparative detour}

(1) Negative particles and speech acts

Before we look at the actual structures, let us take a quick comparative detour.

In English, apart from these negative adverbs and pronouns, we have the sentence negator 'not' and the lexical unit 'no', which can function as an adjective, as in 'no bread' and also forms the negative response to a question. When you look up the word 'no' in the dictionary, it is interesting to see that we are moved from the lexical to the speech act level. 'No' as a negative response has no word class assigned to it but comes under the category 'formulaic expression', 'interjection' or 'speech convention', as of course does the word 'yes'.

In Bengali the word $n a$ is both the sentence negator and the negative answer to questions. Linguistic terminology is unsatisfactory here. Formulaic expressions are phrases such as excuse me, thank you, pardon, goodbye and hello in some definitions, other sources list phrases like by the way, as a matter of fact, if you will, more or less - interjections are words like ah, well, eh, hmm and oh. Should the words 'yes' and 'no' be considered equivalent to these?

It seems to me that what the above expressions have in common is that they are non-essential parts of speech, whereas the words 'yes' and 'no' can convey crucial information. The New Collins Dictionary classes the word 'yes' as 'sentence substitute' - perhaps this is more appropriate, though it is still rather vague. I do, however, agree that in order to classify words like 'yes' and 'no' satisfactorily we have to step outside the lexical word class enclosure and recognize their illocutionary force.

Both 'no' in English and $n a$ in Bengali can stand as statements on their own. There are other ways of answering a question in the negative. In English we have phrases like not at all, far from it, in Bengali mōtei na 'not at all', emotive expressions like $d \bar{u} r$, which literally means distance but is used to strongly reject a suggestion, and words with negative prefixes such as osombhob 'impossible'.

For the purpose of clarity I will make a distinction between what I will call the illocutionary $n a$, which is used as a negative answer to questions, and an adverbial $n a$ in connection with verb forms.

\section{(2) negative potential}

The fact that Bengali has no negative adverbs and pronouns seems at first sight to constitute a lack. In English we can make subtle distinctions, as between 
'I've said nothing' and 'I haven't said anything', the first version of which is more definite. Bengali does not have this option. Nor does it employ emphatic negatives like not ever, never ever, none at all. Indefinite adverbs kōtha $\bar{o}$ 'somewhere', kokhono 'ever', and pronouns keu 'someone', karō 'someone's', kichu 'some', kōno 'any', etc., are used in conjunction with a sentence-final negation. Some simple examples with the English negatives and the Bengali indefinites underlined are given in Table 2.

From Table 2 it may seem that Bengali is more restricted than English in expressing negative concepts, but a closer analysis of Bengali patterns will show that through devices like flexible word order, negative verbs and nonfinite structures a great range of expressions is available. But what about more complex sentences?

The sentence-final negative can serve to negate more than one indefinite adverb/pronoun, and the English translation of the sentence shows that, in spite of its greater lexical range, English does not, in standard speech, allow more than one negative element per sentence either, whether this be an adverb or a sentence negator. Instead the first negative adverb/pronoun causes all subsequent adverb/pronouns to appear in their indefinite form, as shown here:

\section{keu kokhono ei kotha janbe na No-one will ever know about this.}

ora kokhono kauke kichu bolbe na They will never tell anybody anything.

\section{Negation patterns in Bengali}

As Anderson (1920) rightly says, the negative particle $n a$ is added after the verb. I will, for the moment, consider $n i$ to be a tensed version of $n a$ and discuss the relationship between the two forms further on (see under III, 4). But we still have two other sentential negative elements whose uses need to be looked at.

Purely on the surface structure we have three basic syntactic patterns:

- sentences with the negative element no-;

- sentences with the negative element nei;

- sentences where $n a$ (or $n i$ ) is added to the verb.

Both no- and nei can be considered negative verbs, which means that they occur in sentences where no other verb form is present and can therefore be assumed to contain the verbal element. Bengali linguists, including Pabitra Sarkar, list no- and nei indiscriminately together as forms of negation. As far as I know, no one has attempted a proper differentiation and comparison of the two verbs. In order to make clear the syntactic nature of this study the verb nara 'be unable to' should be briefly mentioned. This verb is analogous to the verb para 'be able to' and is no longer in common use. In spite of its

Table 2 .

\begin{tabular}{|c|c|c|}
\hline English & Bengali & gloss \\
\hline Nobody knows. & keu jane na & anyone does not kno \\
\hline Nothing needs to be said. & kichu bolar dorkar nei & $\begin{array}{l}\text { something of the saying } \\
\text { need is not }\end{array}$ \\
\hline They will never lose this. & $\begin{array}{l}\text { öra seța kokhono } \\
\text { harabe na }\end{array}$ & they ever will not lose this \\
\hline I have no doubts. & amar $\underline{k \bar{o} n \bar{o}}$ sondeho nei & my any doubt is not \\
\hline
\end{tabular}


negative meaning it is syntactically a regular verb and has no unusual features which concern the negation structures of Bengali.

\section{(1) Sentences with the negative element no-}

This is a negative verbal element; it is not used in connection with other verb forms and is the negative of the zero verb. The zero verb in Bengali has often been interpreted as the absence or omission of a verb form in the present tense. I disagree with this reading and have discussed it in detail in the chapter on verbs of being in my $\mathrm{PhD}$ thesis. The zero verb is the true copula in equational sentences. Neither hooya with its semantic properties of 'becoming' nor achwith its existential features can fulfil this role. The confusion which has existed around these structures for many years is perpetuated by Bengali scholars when they classify the noi, noo, noy, non forms as 'the negative na with copula verb hooya (Dakshi 1995: 137). This classification is wrong on both counts: the noi, noz, noy, non forms are not the negative forms of hoi, hoo, hoy, hon, and hooyy is used as a copula only in a very few specific cases. One of them is the use of third person present continuous hocche and simple past holo as a procopula, e.g. aj holo budhbar 'today is Wednesday'. These forms are never negated. A detailed discussion of these can be found in my thesis. Another use is the definition of human relationships and this is the only case where the forms of no- can be interpreted as a direct negative to forms of hooya, as for instance in:

se tommar ki hoy, literally: 'What is he to you?'

to which the answer would be:

se amar bhai hoy 'He is my brother'.

The negative of this is se amar bhai noy 'He is not my brother', but there is a subtle shift in focus here. se amar bhai hoy makes a statement about a relationship, se amar bhai noy makes a statement about a person. The difference is, however, slight, and I have found no occurrences of se amar bhai hoy na.

I have no argument with Chatterji who says that etymologically the form noy is a contraction of na hoy. This is on the morphological level and sounds probable but in modern usage and from a syntactic point of view noy and hoy na are quite distinct.

hoōya like other verbs, negates with na

ekhane gom hoy Wheat grows here.

$\rightarrow$ ekhane gom hoy na Wheat doesn't grow here.

kalke brsți hobe There will be rain tomorrow.

$\rightarrow$ kalke brstiti hobe na There will be no rain tomorrow.

tar osukh hoyeche He has been ill.

$\rightarrow$ tar osukh hoy ni He has not been ill.

This is the only correct way of negating these sentences.

The verb no- has the present-tense conjugated forms only: noi (for first person), noo (for second person familiar), noy (for third person familiar), non (for honorific forms, second and third person). There are no non-finite verb forms, no imperatives and no other tenses. The stem no- as well as the verbal noun, which is given as noha in the Samsad Dictionary, are assumed dictionary creations with no existence in real language. The old forms nohi for noi and the equivalent forms for second and third person are now obsolete. There is a conditional participle noile which is used in alternation with na hole if this is not so', but its semantic features are not in line with the conjugated forms and I 
would consider it a separate lexical entity. I will come back to this. Forms of no- appear in simple sentences such as:

(1) boita amar noy The book is not mine.

(2) aj budhbar noy Today is not Wednesday.

(3) gachța beśi boro noy The tree is not very big.

(4) baba nobì non Father is not a prophet.

All these examples in their positive form would have the zero verb. Past tenses would be with chilo na, the negative past tense of ach-, the future tense is most likely with a form of hooya 'be, become', the conditional also with hoōya. This touches on the complex issue of overlap among the Bengali verbs of being, and requires separate treatment.

But let us look at some real examples, moving from simple to more complex structures (all from kali ō kolom):

(5) amar tō niścito noi. But we are not sure.

(6) ei ki yotheșto noy? Is this not enough?

(7) se poth amar noy. This is not my way.

(8) amar kaje ami mōtei trpto noi. I am not at all satisfied with my work.

(9) kebol mukher kotha noy. (They) are not just empty words.

(10) lekhok bōdh hoy praibhet biśvobidyaloygulo somporke khub beśi obohito non.

The writer is perhaps not very familiar with private universities.

(11) eta komitir siddhanto, amar ekar noy.

This is the committee's decision, not just mine alone.

(12) ekhan theke koto dūr apnar bari? beśi noy.

How far is your home from here? Not far.

It has to be kept in mind that the function of a copula is to link (or equate) two elements, the subject and its complement, though the subject can sometimes be omitted, as for instance in sentence (9). Even with more complex structures it is possible to reduce them to their essentials in order to see the logic. The basic positive structure is [Subject] equals [Complement], with the subject either a noun or a pronoun, the complement a noun, pronoun or an adjective. In sentence (12) we have an interesting example of a locative context, which is normally associated with ach-and therefore nei, but if we look more closely we see the equational element: dūr beśi noy 'The distance is not great'. As we shall see in section IV there are a number of areas where the uses of noy and nei can indeed come very close, and careful thought or reliable intuition is needed to distinguish between the two.

In addition to this verbal role, noy has a modal sentence function expressing appropriateness or acceptability. This appears, though not frequently, in connection with certain non-finite verb forms. Two instances are as follows:

(i) noy following a conditional participle: ajke na gele noy, which translates as 'It won't do if (we) don't go today'.

(ii) noy following a verbal noun in the genitive: eta hooyar noy, 'This is not supposed to happen'.

Both of these structures contain a modal element and go beyond mere negation. An overview of these and other modal structures involving non-finite verb forms is given at the end of section (2) but I have not yet found sufficient examples to come to any firm conclusions about their internal composition. 
(2) Sentences with nei

This negative verbal form is unchangeable and is the negative of ach- 'to be, to exist, to be present'. On the surface this is very simple. ach-itself is an incomplete verb with only present-tense achi (first person), acho (second person, familiar), ache (third person, ordinary), achen (second and third person, honorific), and the equivalent simple past-tense forms chilam, chile, chilo, chilen, but no non-finite verb forms, no imperative and no other tenses. For these, the verb thaka 'stay, remain' is the substitute.

As learners of Bengali, our first acquaintance with the verb ach is in sentences such as amar gari ache 'I have a car' and its equivalent negative amar gari nei 'I don't have a car'. To translate ach- with 'have' is an approximation. There is no overtly possessive element in ach-; a more accurate translation of amar gari ache is 'my car exists' nei is also the negative for the locative use of $a c h$ - where the verb forms are conjugated. Thus we have:

ami ekhane achi I am here. ami ekhane nei I am not here. tumi ekhane acho You are here. tumi ekhane nei You are not here. se ekhane ache $\mathrm{He}$ (ord) is here. se ekhane nei He (ord) is not here. tini ekhane achen $\mathrm{He}$ (hon) is here. tini ekhane nei $\mathrm{He}$ (hon) is not here.

$n e i$ is therefore the only verb in Bengali which treats me, you, ordinary and honorific, in the same way, and this does, of course, have a compelling logic behind it: absence does not distinguish gods, ghosts or specks of dust. This fairly straightforward semantic concept, expressed by nei, can be divided into two types of absence: absence from a particular place (specific absence (a)) and non-existence (general absence (b and c)). For the convenience of English speakers, sentences denoting general absence can again be divided into those which can be translated with 'have' (b) and those best translated with phrases like 'there is no' (c).

The presence of a logical subject in the genitive usually indicates that a translation with 'have' is appropriate. The following example sentences are divided into groups which show these differences clearly.

(a) examples of specific absence, locative sentences:

(13) uni ajke basay nei. He is not at home today.

(14) keu tō ekhane nei. There is no-one here.

(15) uni emon svostite nei. He is not in such great comfort.

(16) nośțo korar motō poryapto somoy tar hate nei.

There is not a lot of time to waste on his hands. (a clumsy translation!)

(17) amader deśer praibheț biśvobidyaloygulōte bamla bhașar kōnō sthan nei.

In the private universities of this country there is no room for the Bengali language.

(b) examples of general absence with a genitive 'logical' subject, 'have sentences':

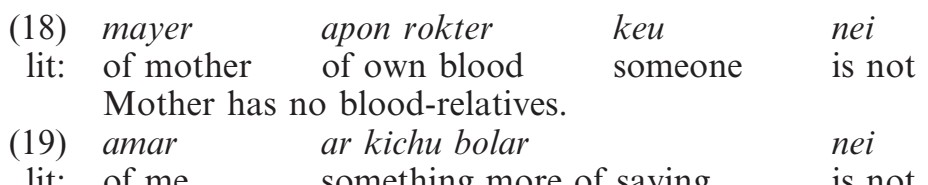

lit: of me something more of saying is not

I have nothing more to say. 


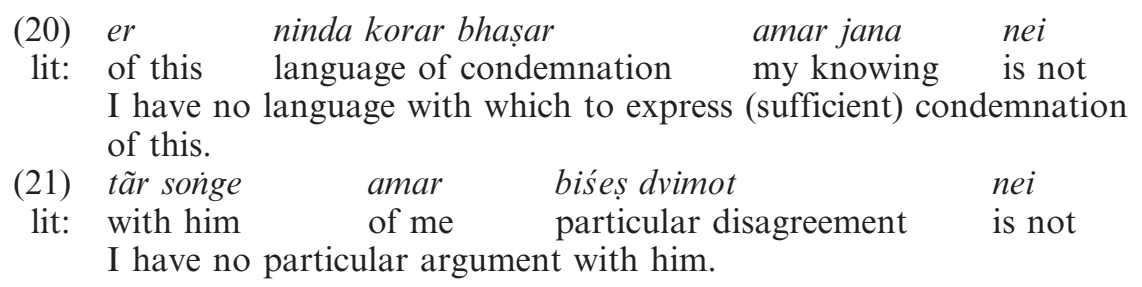

(c) examples of general absence without a possessive element, 'there is not sentences'

(22) ar kōnō poth nei?

Is there no other way?

(23) amake

na cene emon lōk nei

lit: me does not know such a person is not

There is no one who doesn't know me.

(24) er sotyota osvikar korar upay nei

lit: of this truth of the denying way is not There is no way of denying the truth in this.

(25) robindronather sarbik bhabnar phosol $i$ ye

lit: the harvest of all Rabindranath's thinking that in this fair rüpayonkorar cestahoyechilo tate sondeho nei of the shaping there was the effort in this doubt is not. There is no doubt that an effort was made to incorporate all of Rabindranath's thinking into the character of the fair.

My arrangement and interpretation of these sentences is meant to show that, whatever the degree of complexity or abstraction, we have in all of them the underlying simple concept of absence. Particularly in the category of general absence, there are a number of abstract nouns which are commonly used. In sentence (24) we have upay 'way', in sentence (25) sondeho 'doubt'. Other such nouns are dorkar 'need', kotha 'word', proyojon 'necessity', somoy 'time', jayga 'place', karon 'reason', sombhobona 'possibility', subidha 'convenience'. The phrase osubidha nei 'there is no inconvenience' is as common as the English equivalent stock phrase 'no problem'. Syntactically nei almost always follows a noun. In sentences (19) and (20) we have two verbal nouns; amar 'my' (or any other possessive pronoun) jana nei 'I have no knowing' is a common phrase which often, but not always, implies information irretrievably lost or unavailable and the phrase offers a convenient way out of a personal and active statement ami jani na 'I don't know'. In sentence (19) we have a genitive verbal noun bolar 'of the saying' attached to kichu 'something'. This is also a very common structure and is, from an illocutionary point of view, equivalent to shifting the attention away from the speaker. If we compare these two sentences

(i) active ami ar kichu korbo na I won't do anything more.

(ii) with neiamar korar ar kichu nei There is nothing more for me to do.

we see immediately that the structure with nei is not only impersonal but implies an abdication of responsibility. In fact, taking a step away from syntax to the communication level, the word nei in itself has a somewhat fatalistic air and is often accompanied by an open-handed waving gesture to indicate that there is nothing to be done.

Like noy, nei also has a modal role in connection with non-finite verb forms, this time with the infinitive. In ekhane thakte nei 'it is not appropriate 
to stay here', nei adds the element of suitability, permission or acceptability. I have not yet encountered many live examples of this structure, but it belongs to a pattern of a particular type. Some common verbs in connection with certain non-finite verb forms take on a modal meaning, for instance eta hooyar noy 'this should not occur/happen', eta korte hobe 'this has to be done', ekhane thakte ache 'it is permissible to stay here', eta kora yay 'it is possible to do this'. The verbs involved in these structures are predominantly verbs of being and the verbs yāya 'go' and cola 'move'.

Table 3 shows a preliminary overview of these structures.

Table 3 .

\begin{tabular}{lllll}
\hline \multirow{2}{*}{ Non-finite verb form } & + & \multicolumn{2}{l}{ 3rd person verb form } & \multirow{2}{*}{ modal meaning } \\
\cline { 3 - 4 } & & pos & neg & \\
\hline cond. part. & gele & hoy & hoy $n a$ & sufficiency \\
cond. part. & gele & cole & cole $n a$ & sufficiency \\
inf. & yete & hoy & hoy $n a$ & obligation \\
inf. & yete & ache & nei & permission \\
cond. part. & gele & - & noy & appropriateness \\
vbN (gen.) & yaōyar & - & noy & compulsion \\
vbN & yaōya & yay & yay na & possibility \\
\hline
\end{tabular}

\section{(3) The properties of $n i$}

$n i$ has a different status from nei and the forms of no-. It is not a negative verb but a negative particle used together with simple present-tense verb forms, and is usually classified as the negative of the present perfect and of the past perfect. This classification is based on the non-appearance of the expected forms *korechi na (present perfect) and *korechilam na (past perfect), not a very reliable base for interpretation. What we do know is that, in addition to the simple present negative ami kori na, we have the structure ami korini and that there is clearly a difference of tense between these two forms in that ami korini has a past tense meaning. This is a vague but safe place to start.

Rafiqul Islam in his 2001 condensed grammar Bangla Byakaran Samikha points to a fundamental difference between $n a$ and $n i$. $n a$ is an independent particle, $n i$ is not. In written language $n i$ is often attached to the verb form, $n a$ is written separately. But this is merely a convention and has no bearing on the internal connection between these forms. A Bangladeshi variation of $n i$ is nai, and this is frequently separated from the verb form in writing. From what we have seen earlier, there is no doubt that na has the monopoly on being the illocutionary negative particle, but how does $n a$ differ from $n i$ in its adverbial use? In addition to its negative function $n i$ has a tense element built into it and is therefore more closely linked to the present-tense verb form-it has a doubly changing effect on the verb form. Rafiqul Islam makes much of the fact that $n i$ cannot stand on its own and this is a valid observation. $n i$ always follows a simple present verb form directly, no adverbial can be inserted between the verb and $n i$, and $n i$ never occurs on its own in answer to questions.

It is disconcerting to see that even something as basic as the actual verb forms used is a matter of disagreement. Qazi Din Muhammad calmly states that 'the use of the particle $n i$ with the simple present is found to function as the corresponding negative implications of the perfective present and 
progressive and perfective past in all aspects and persons and grades' (1963: $33)$. What he is saying is: ami khai ni is the negative not only of the present perfect ami kheyechi and past perfect ami kheyechilam but also of the past continuous ami khacchilam. Smith (1997) makes no mention of the past continuous in this context but allows the occasional use of korechilam na (the past perfect) (p. 23). Our starting position is therefore far from clear. In order to refute Muhammad's claim, all we need to do is to find some examples of past continuous uses with na and this is easily done.

(26) bhïruta katiye uthte parchilen na onuradha Onuradha was unable to overcome her fear. osommanta ekebare bhulte parchilen na He was unable to forget the slight.

These sentences suggest that the ni negation does not apply to the past continuous but they are taken from the same novel and both involve the verb para 'be able to' so we need to look a bit further.

(28) ami kichu bolchilam na I wasn’t saying anything.

(29) pronobeś ki uttor deben bhebe pacchilen na She could not imagine what Pranobesh would reply. sthir thakte para sombhob hocchilo na It was not possible to remain quiet.

All of these are instances of past continuous verb forms negated with na, and since this confirms the general consensus on which tenses are affected by the $n i$ negation, we can safely assume that Muhammad's claim is wrong. Smith's statement that the past perfect negative is occasionally formed with $n a$ is more difficult to refute - the fact that I have not found any examples for this is insufficient proof. But since he is talking about an occasional occurrence rather than a grammatical rule, we can leave this with a question mark.

It is much more important and interesting to try and establish the semantic properties of these ni structures. Designating the present and past perfect as their area of application is a default solution and does not yet tell us very much. In dealing with real language we cannot speculate about what a sentence would have been without the negative element. We can only go by what we find, and it is reassuring to find sentences like:

(31) sabu ar tar premik eksathe thakte śuru koreche ki koreni khobor peye lōktir strī gãye hajir holo

The man's wife turned up in the village with news about whether Sabu and her lover had started living together or not.

where the positive koreche and negative koreni forms appear in direct juxtaposition.

An indication of past perfect contexts is given in these examples:

(32) kichu ekța bolte ceșta korechilen tini kintu golar svor phōteni He tried to say something, but his voice failed him. (lit: his voice didn't emerge)

tarpor thik ki hoyechilo tãke janayni se

Exactly what happened afterwards, he didn't tell him.

These are fairly firm indicators of a tense-context, but from a functional point of view we are on safer ground referring to the structure in question as the $n i$ past tense rather than as the present and past perfect negative. 
In order to get a firmer grip on these structures, let us have a look at pasttense negative verb forms in general. In sentences (29) and (30) the past continuous negative forms have a particular purpose and are the logical forms to use. Bengali tense use often seems arbitrary to us but it has its own semantic logic. Both these verb forms occur in narrative, simple past contexts. In sentence (29) the past continuous tense expresses the ongoing frustrating worry about what the husband's reaction might be. In sentence (30) the continuous verb form, in spite of the stative properties of sombhob hooya 'be possible' adds the itchy restlessness which the author wants to convey. No other tense would have had the same effect. These kinds of examples are not frequent but when they do occur, they are used for specific purposes. In neither case is the $n i$ past tense a likely alternative. Apart from the past continuous we have the simple past ami khelam na and the past habitual ami khetam na. In order to establish the role of the $n i$ past tense, we need to take all these forms into account. Anderson is wrong when he says that the simple past korlam na is unusual. There are plenty of examples like (34) with or without time adverbials:

$$
\begin{aligned}
& \text { se din ar keu elo na } \\
& \text { No-one else came that day. }
\end{aligned}
$$

Gillian Ramchand in her article 'Two types of negation in Bengali' sets out to ascertain the semantic range of the $n i$ past tense through the analysis of linguistic features and with complete disregard to traditional categorization. We need this kind of purely linguistic focus because it offers an objective analysis of contemporary language. If we want to classify the ni form appropriately, we need something more tangible than somewhat arbitrary traditional assumptions.

Ramchand's article offers a new approach and I was fascinated by her attempt to prove that the present perfect is semantically incompatible with the $n a$ negative. I was thinking along the same lines and would have liked to come up with a clear semantic distinction between sentences like ami khelam na (simple past with na) and ami khai ni (ni past tense). One fairly clear semantic component is that of volition. While ami khai ni is the simple reporting of a fact, ami khelam na contains a deliberate element 'I didn't eat because I didn't want to eat'. Ramchand sees the distinction in the aspective features involved in the two tenses, the simple past and the present perfect. Briefly stated, she says that a perfective aspect cannot be made incomplete. A comparable structure in English is a sentence containing 'already' which represents a perfective/ completive aspect. The only way to negate an already completed action is to abandon the completedness and revert to an unfinished state of events by replacing already with yet, e.g. 'I have already seen him' becomes 'I have not seen him yet'. In the move from the completed ami kheyechi 'I have eaten' to a negation of this event we have to change the completive verb form. The reasoning behind this can be shown even more clearly if we look at the common Bengali compound verb structure of a perfective participle plus the verb phela 'throw'. In many ways, this structure is the epitome of perfectivity or completedness. ami bhat kheyechi means 'I have eaten' or 'I have eaten the rice'. ami bhat kheye phelechi means 'I have eaten the rice up'. This sentence cannot be negated. In order to express the negated concept, the verb phela, with its completive aspect, needs to be removed and the simple verb form restored ami bhat khai ni or ami bhat śeșkori ni 'I have not finished the rice' i.e. 'there is still some left'.

Ramchand's analysis is thorough and careful and adds a new perspective to the understanding of these forms. She lacks, however, a realistic view of 
Bengali tenses. This is perhaps simplifying her arguments more than is admissible but it seems to me that her understanding of the present perfect is based on this aspective feature of completion, a telic reading, whereas the simple past has to her an inherently atelic character. These issues need further consideration, but they take us far beyond our present topic to a semantic analysis of Bengali tense use. Add to this the distributional factor of these tenses: the main use of the simple past is in narrative text while the $n i$ past tense is the more common tense in spoken language.

In order to gain a clearer understanding of the ni past tense, I have carried out a random study of narrative texts (mainly fiction) on the initial assumption that the $n i$ past tense does not mix well with simple past tense storytelling. From normal everyday spoken use of the form, it is easy to get the impression that it has a 'not yet' feature built into it. If we compare the simple past ami bajare gelam na and the ni past tense ami bajare yai ni both sentences can be translated as 'I didn't go to the market'. In order to clarify the difference between these two sentences, we can add time adverbials and have
simple past
(i) ami gotokal bajare gelam na
I didn't go to the market yesterday.
ni past tense
(ii) ami ekhonō bajare yai ni
I haven't yet gone to the market.

This is the kind of pattern we would like to find and which corresponds well with English tense use, i.e. the semantic difference between simple past and present perfect. It is also the pattern that Ramchand identifies. Using time adverbials to test semantic features is a valid and useful procedure and, indeed, in a great number of cases the distribution of time adverbials seems to confirm our desired pattern. Let us look at some examples:

(35) ekhane emon kichu ekhonō ghoteni

Nothing like that has happened here yet.

(36) apnake tō bola hoy ni

You have/had not been told.

(37) keno etodin tōmar songe yōgayōg rakhte parini, seța tōmar ōjana noy You know why I was unable to stay in touch with you for so long. ami onek khȭj korechi kintu kopi pai ni

I searched a lot but have not found any copies.

se kokhonō biyete raji hoy ni

She has never agreed to marriage.

Even in the absence of overt time adverbials these sentences have a perfective character which indicates a future change, e.g. in (36) it can be assumed that the addressee will now be told, in (37) that contact has now been restored, in (39) that the lady in question is now changing her mind about getting married. But is the use of the ni past tense restricted to such contexts? What about its use in simple past narrative contexts? Given the fact that in such contexts we find frequent leaps to the simple present or the past perfect and therefore a general instability of tense use, there is no indication at all that the ni past tense does not fit into these contexts. Here are three poignant examples:

(40) pronobeś yokhon nije theke boleni tokhon e niye kōutuhol prokaś korața obhabonìyo

When Pranobesh didn't say anything himself, it would have been unthinkable to reveal his curiosity. 
(41) tar bōn tulu bombete phōn korechilo. tader khobor nebar por laința pronobeśke dite bollo. omla tokhon take bolen pronobeś bombete nei. kōthay gechen seța tulu jante cayni

His sister Tulu phoned Bombay. After hearing their news she asked to speak to Pranobesh. Amla told her that Pranobesh was not in Bombay. Tulu didn't ask where he had gone.

(42) strìr songe mithyacarer jonyo kharap lagchilo pronobeśer. kintu e chara ki korar ache? moner gōpon alōchaya-ghera omíe ãtipãti kore khüjeō protaroṇar samanyo obhiyōgțkuō paōya gelo na. na omlake tini thokanni

Pranobesh felt bad about lying to his wife. But what else could he do? Even diligently searching the darkest recesses of his mind he could find no charge of deceit. No, he had not cheated Amla.

In (40) we have in one neat sentence a convincing indication that the $n i$ past tense can occur with a fixed point time adverbial (yokhon) and refer to a past event. In (41) we have a simple series of events with the usual mixture of tenses. We have two negatives. The first one pronobeś bombete nei is reported speech. In Bengali this is usually conveyed directly, so the simple present in this sentence is expected. The second one is in the $n i$ past tense. Out of the many passages I examined I chose this relatively simple one to show that the $n i$ past tense is used for completed actions (or non-actions) in the past without any indication of our 'not-yet' feature. Example (42) is even more convincing. The last sentence na omlake tini thokanni serves as a summing-up of a past tense train of thought and actions with no connection to the present tense. A more thorough investigation will have to be done on these past-tense negatives, but this should be in connection with tense use in general.

In addition to these fairly straightforward findings, it is becoming increasingly clear to me that there is a style issue involved here. The more colloquial the style, the more $n i$ past tenses appear. In novels with a more formal style we often have a change to the simple present or the present continuous for negative statements. It is almost impossible to draw any firm conclusions on this, but we can be sure that the $n i$ past tense is a fully participating member of past tense narrative verbal variations.

\section{Syntactic realities}

(1) Overlap of nei and noy

Learners of Bengali have a certain amount of difficulty in distinguishing between the uses of nei and noy. We can explain to them that nei is the negative of ach-, noy the negative of the zero verb; we can say that sentences with nei involve absence, sentences with noy the non-equation of two elements, but the structures can indeed become very close. If we look at example sentence (3) se poth amar noy 'this is not my way' we can replace noy with nei and translate the sentence as 'I don't have that option'. We may want to change the word order to amar se poth nei to see that this is the same structure as amar gari $n e i$ 'I don't have a car'. But word order is fairly flexible in Bengali and the underlying structure is not always easy to detect. In Milne's Practical Bengali Grammar we find the sentence:

bina nimontrone sekhane yaōya amar iccha noy

I don't wish to go there without an invitation. 
Milne's book has many errors in it and we are tempted to regard this as one of them because we expect amar iccha nei 'I have no wish'. But a nei structure would clearly require the verbal noun yasya to be in the genitive: amar sekhane yaōyar iccha nei 'of me the wish of going is not'. With a nominative verbal noun an equational reading is entirely possible 'to go there my wish is not'. The meanings are to all intents and purposes the same, but the example shows not only that these kinds of sentences need very close reading, but also that the fluctuation between nominative and genitive verbal nouns, which is sometimes dismissed as sloppiness, in fact has a much more solid syntactic basis. Syntactically, in structures with nei the immediately preceding noun is the sentence subject, while everything else serves to modify this subject, e.g. amar sekhane yaōyar dorkar nei 'of me the need of going is not', dorkar 'need' is the subject and amar sekhane yaōyar 'of my going there' qualifies this need. In structures with noy we are dealing with two nominative elements, the subject and the complement in an equational relationship.

This relationship status can sometimes be obscured by omission of the subject. We had this in sentences (9) and (12) and we have it here:

(43) ekhon somoy protibad korar protibad śudhu noy protirōdh korar Now is the time to protest, not only to protest, but to prevent.

The basic sentence is somoy protibad korar noy 'the time is not to protest'. This is a more uncompromising statement than ekhon protibad korar somoy nei 'now there is no time to protest' would be, and it shows that the abstract nouns mentioned above are by no means automatically linked with nei. In some sentences the copulative structure is plain to see:

(44) manuṣ śudhu premer karoṇe noy

Human beings don't just exist for love.

But in sentences like (45), again from Milne, we need to identify the nominative subject taha 'that' in order to grasp fully the structure.

(45) se ye amake ki birokto kore tuliyechilo taha ar bolibar kotha noy I can't adequately express how greatly he annoyed me.

The second part of the sentence can be glossed as

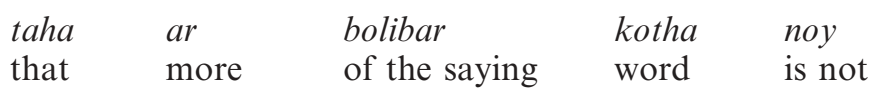

If we leave out the non-essentials ar 'more' and bolibar 'of the saying', and look at

$\begin{array}{lll}\text { taha } & \text { kotha } & \text { noy } \\ \text { that } & \text { word } & \text { is not }\end{array}$

we see that this is exactly parallel to, for instance,

$\begin{array}{ll}\text { ta mithya } & \text { noy } \\ \text { that lie } & \text { is not } \\ \text { 'That is not a lie'. } & \end{array}$

This detailed demonstration of a structure which is intuitively accessible to native speakers has a significance beyond the learning needs of foreigners because it offers a real insight into the way syntactic structures reflect semantic realities. This level of understanding opens up the logic of Bengali grammatical structures in a new way and alerts us to these intriguing case variations. 
Here are three sentences from Abdul Rouf Choudhury's novel Pordeshe Porbasi, which show the same pattern.

(46) tobe ekșetre somoy tō boro kotha noy

But time is not the real issue here.

The equational structure is easy to see here. In both the following sentences, however, a combination of kotha with nei would be more usual, and we note that the use of noy causes the sentence subjects (niculok (47) and osubidhe (48)) are in the nominative, where nei would have required the genitive. The possible $n e i$ versions of the sentences are given in brackets:

(47) imlyaṇụe tō krṣoker mōto niculōk thakar kotha noy (imlyande tō krssoker mōto niculōker thakar kotha nei)

But in England such lowly people as farmers are not supposed to exist.

(48) apnar kōnō osubidhe hoōyar kotha noy (apnar kōnō osubidhar hoōyar kotha nei) You are not supposed to have any problems.

These examples show the complex internal structuring of Bengali sentences. Unfortunately, the matter does not end there. Whilst it is true that sentences with noy need a nominative subject, they do not always have a nominative complement. We have seen this in simple structures like

$\begin{array}{lll}\text { boyti } & \text { amar } & \text { noy } \\ \text { the book } & \text { mine } & \text { is not }\end{array}$

'The book is not mine'.

But we also find it with verbal nouns

(49) e kolkatar gongay ki ek tan ache taha bhōlbar noy There is some attraction in the Ganges in Kolkata which is unforgettable.

For our purposes, we need only look at the basic structure

$\begin{array}{lll}\text { ta } & \text { bhölbar } & \text { noy } \\ \text { that } & \text { of the forgetting } & \text { is not }\end{array}$

There is no sign of any hidden, modal meaning in this. If we had come across this sentence in isolation, we might have taken it as an instance of ellipsis, short for ta bhölbar jinis noy 'this is not a thing to be forgotten' but alongside the simple boita amar noy 'the book is not mine' we can accept it as a complete sentence and at the same time take note of the wide semantic range of the genitive. As I said at the end of section (1), I do not yet have enough examples of this kind for a proper analysis and, taking sentence (49) into account, it is clear that the modal character of these structures is by no means certain. Nor are the structures themselves clearly defined.

Both the infinitive with nei and the genitive verbal noun with noy express a prohibition, though whether these imply a strict 'must not' or a less severe recommendation 'not to' has not yet been examined conclusively.

We can have:

$\begin{array}{lll}\text { pōna mach } & \text { dhorte } & \text { nei } \\ \text { fingerling } & \text { to catch } & \text { is not } \\ \text { 'To catch fingerlings is not allowed'. } & \end{array}$


or
pōna mach
fingerling
dhorbar
of the catching
noy
is not

'Fingerlings are not to be caught'.

In sentence (52) we have, with the same structure, an element of necessity rather than prohibition.

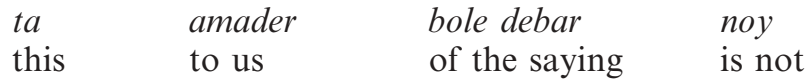

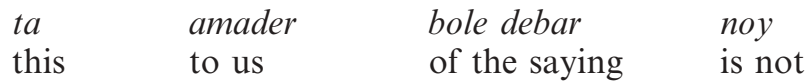

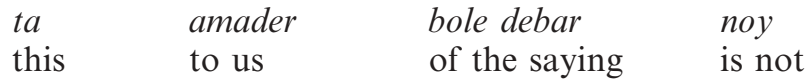
We don't need to be told this. Or, indeed
It is not up to us to say this.

The modal element is there in these sentences but it seems to have a wide semantic range. The syntactic scaffolding alone does not tell us enough.

(2) Positioning of $n a$

This section can be subdivided into the following occurrences of na:

(i) $n a$ following a finite verb form;

(ii) $n a$ preceding a finite verb form for emphasis;

(iii) na preceding a finite verb form in subordinate clauses;

(iv) $n a$ preceding a non-finite verb form.

(i) The negative particle $n a$ follows the verb and, since verbs usually come at the end of sentences, $n a$ is generally the last word in a sentence. Rafiqul Islam interprets the fact that $n i$ is usually attached to the verb form as a particularly close connection. The connection between verb form and $n a$ is, however, almost as close. I have found only one instance of the particle to inserted between the two.

(53) arō dujon yatri peye gele tōmake niye yete kōnō osubidha hobe na kintu pacchi tō na.

If two other passengers can be found, there won't be a problem taking you. However, I'm not finding any.

$t \bar{o}$ is an adversative particle which strengthens the effect of kintu 'but'. It could just as easily have been placed after $n a$. Examples like this-and there are only very few-show that the verb form and $n a$ are not entirely inseparable but that they have a strong adherence to one another.

There are two regular patterns for na preceding the verb and they are syntactically linked to one another: subordinate clauses and non-finite verb forms.

(ii) But first we have an emphatic use of $n a$ :

na ache baimla bhașa, na ache baimla bibhag

There is no Bengali language and there is no Bengali department.

na yabo bombete, na yabo kōthā̄, ekhanei thakbo tōmar songe

I'm not going to Bombay, I'm not going anywhere. I'll stay here with you.

These examples are relatively rare but all the more striking. In (54) we have not only a reversed order of verb and negative particle but also the combination of ache with na. Ferguson has another similar example: 
(56) sekhane na ache ghor-dor, na ache kichu

There are no houses there, there is nothing.

It seems from these few examples that this word order is linked to an anaphoric sentence arrangement, a string of parallel structures. This use of na before a finite verb form can be considered a rhetoric device for emphasis. One other instance of preceding $n a$ is found in (57) with a third person imperative:

amar chele ache. ar keu aśroy na dik, se debei

My son is there. Let no one else give shelter-he will give it.

It seems likely to me that this is the normal position of a negation with a third person imperative rather than an emphatic device, but I have not seen enough examples to corroborate this. For the moment, I will classify it here.

(iii) The system of subordinating clauses and their relationship to the main clause is quite different in Bengali from in English. Although my research in this area is still incomplete, I can make some preliminary comments. Every subordinating conjunction has a corresponding conjunction in the main clause. In fact, the existence of a correlative in the main clause can be taken as a definitional feature for subordination in Bengali. Conjunctions without a correlative are coordinating. We have here a very interesting overlap of word classes which has not been recognized as such. The familiar concept of relatives and co-relatives is recognized for relative clauses of the type ye-se 'he-who', $y a-t a$ 'that which' and by extension for conjunctions like yemon-temon as-as. It also applies to pairs like yodi-tahole 'if', yodiō-tobuō 'although', yokhon-tokhon 'when'. Instead of having a clear distinction between pronouns and conjunctions, we have the phenomenon of correlation, to which pronouns as well as conjunctions are subject.

But how does this affect negation patterns? The particle na can precede a finite verb form in subordinate clauses, but not in main clauses, except for emphatic use as shown above. With some conjunctions this change in word order is almost obligatory, e.g. in sentences with yodi 'if'.

$\begin{array}{ll}\text { tumi yodi na yaō } & \text { if you don't go } \\ \text { uni yodi ese na thaken } & \text { if he hasn't arrived } \\ \text { brsți yodi na hoto } & \text { if it didn't rain }\end{array}$

With other conjunctions the positioning of $n a$ seems to be linked to aspectual features such as progressiveness:

(58) yotokșon na rumi asche ekhanei opekșa korben

As long as Rumi didn't turn up he would wait for her here.

In the same novel, a few paragraphs later, the same concept is given with yokhon - na appears after the verb.

(59) yokhon rumi elo na tokhon sōja keyatolay phire elen

When Rumi didn't turn up he went straight back to Keyatala.

The difference between yotokșon and yokhon is their extension in time. While yotokṣon refers to an extended period 'as long as, for as many moments as', yokhon gives us a point in time 'when, at that moment'. In another context we find:

(60) kintu yotodin na prthibī dhvomiso hocche, totodin tō manuṣer onner somisthan korte hobe 
But as long as the world is not on the point of extinction, provisions have to be made for man to eat.

We can therefore provisionally state that with durative conjunctions the negative particle is drawn into the phrase, appears before the verb form and often, but not always, forms a close semantic unit with the conjunction, implying 'as long as not', whereas with positional (point in time) conjunctions, na comes after the verb form.

In an essay on the difficulties of unifying the language, very poignantly, there is:

(61) yotokṣon nirokṣorta dūr na hobe eboin deśer sorbosadharon ontoto ekhonkar obosthay ō ek śo joner modhye śotokora șațon sotyii śikșalabh na korbe totodin bamilabhașar ō unnoti duhsadhyo

As long as illiteracy is not abolished and while at least at the moment $60 \%$ of the population don't benefit from education, an improvement in the Bangla language is hard to accomplish.

What does the author mean by improving the Bangla language? There does not seem to be much wrong with it and it is clear that the negative particle plays its own subtle role in the semantic interplay of sentence parts and in retaining the internal balance which is so typical for this language. In the cases where $n a$ is placed before the verb it loses its exposed sentence-final power but it gains a stress which is never present when $n a$ follows the verb.

(iv) $n a$ preceding a non-finite verb form: I started with the hypothesis that in Bengali all negation is on the sentence level, that $n a$ at the end of a sentence negates the whole sentence. But this somewhat rigid regime is loosened up in connection with non-finite verb forms. Non-finite verb forms play a crucial role in Bengali syntax. In fact, they are so prominent that where two or more actions or events are related and reported together, a non-finite verb form is almost always the first port of call. Subordinate clauses with finite verb forms are usually only the back-up option. Let us have a brief look at what non-finite verb forms can do in places where English has subordinate clauses.

English subordinating conjunctions can be grouped into the following semantic areas:

- Time (after, before, when, while, since, until)

The perfective participle can deal with anything related to sequences of events (when, after, before). The present participle exists for the purpose of expressing simultaneity (while). For 'since' and 'until' the verbal noun with the postpositions theke 'from' and poryonto 'until' are the obvious choices.

- Cause and effect (because, since, now that, as, in order that, so)

The locative verbal noun can express cause, so does the genitive verbal noun with the postposition jonyo 'for' (because, since) or the postposition pore 'after' (now that). Anything relating to purpose or effect can be expressed through an infinitive (in order that/in order to).

- Opposition (although, even though, whereas, while)

The adversative particle $\bar{o}$ added to the conditional participle or to the perfective participle can cover most of these meanings. Verbal nouns with postpositions such as sottveo 'despite' or poriborte 'instead of' have a similar function.

- Condition (if, unless, whether or not, even if, in case)

Again, the conditional participle is the main candidate for expressing these concepts. Verbal nouns with the postposition pache 'unless' offer another option. 
This very roughly indicates the wide range of non-finite uses in Bengali and it is no wonder that negation patterns are also affected by it. By positioning the negative particle $n a$ before non-finite verb forms we gain dramatically the possibility of internal negation. I will restrict myself to two examples for each verb form. There is often a considerable difference between the Bengali sentence structure and an idiomatic English translation, so an approximate gloss is also given.

-Verbal noun

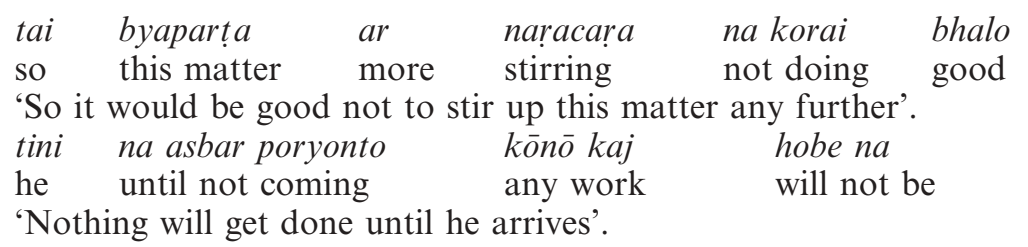

The nominal character of verbal nouns has the effect that a preceding $n a$ becomes almost equivalent to a prefix so that we think of non-arrival, nonoccurrence. But this melding together of negative and verb form is not restricted to verbal nouns.

- Conditional participle

Glosses for the conditional participle are given as 'if doing, going, saying', etc. This is not very idiomatic in English but it preserves the person-neutral character of the form.

$\begin{array}{llll}\text { kokhonō kokhonō } & \text { jōr } & \text { na korle } & \text { cole na } \\ \text { sometimes } & \text { force } & \text { if not doing } & \text { does not go }\end{array}$

'A little bit of force now and then is necessary'.
sokal na hole
kichui
kora
morning if not becoming something the doing will not go
'Nothing can be done before morning'.

In (65) we have the very common form na hole 'if not becoming', which is used by itself as a conjunction meaning 'if not, otherwise'. Here again one feels that the negative and the conditional participle meld into one semantic unit.
na paōya
not finding
gele
ek ek kore
onyo haramjadagulōr bari
one by one
the houses of the other scoundrels
yabo
I will go
If she is not found I will go to every single house of the other

In sentence (66) it is difficult to decide whether the negative particle belongs to the verbal noun or to the conditional participle. The two non-finites form such a close unit that the negative embraces both forms and a change to paōya na gele 'the finding, if not going', would, in my opinion, make no difference.

The occurrence of na hole in sentence (65) and dealing with conditionals brings us back to the peculiar role of noile 'if not, otherwise', which was mentioned earlier on. As I said, I feel that this form has moved away from its original, verbal character and has become an isolated lexical unit. There are many cases where verb forms take on the role of another word class. We have diye 'having given', niye 'having taken', kore 'having done', theke 'having stayed'all of these can all but lose their verbal character when used as postpositions 
or adverbs, but they can at any time revert to being full verb forms. The form noile has lost its environment. There are cases where na hole and noile are interchangeable, but in (65), for instance, noile could not be used because it is no longer capable of fulfilling its conditional function within a syntactic structure. It is not possible to say *sokal noile nor even *ta noile. Let us look at the following three sentences to establish the uses of noile.

-noile

(67) prothome khȭj kore dekhben ekhon histri klas hocche kina. yodi hoy opekșa korben. noile ei diparțmenter chatrochatrī beyara yake pan take onurōdh korben...

First he will find out if there is a history class going on now. If so he will wait. If not, he will ask the students or staff of this department $\cdots$

In this sentence noile appears in direct juxtaposition to yodi hoy 'if it is' and has its full conditional character.

(68) rate ghumer modhye seța bujhiya theke geche. noile sokal uthtei take mone porbe keno

This understanding must have come to him during his sleep in the night. Otherwise why would it be on his mind as soon as he woke up in the morning?

The syntactic relationships are getting blurred here. There is no longer any sense of equating a subject with a complement-instead noile calls the whole previous statement into question. This is by far the most common use of noile, at the beginning of a sentence with no syntactic ties. Sentence (69) makes this even clearer:

(69) tãr esomoy kolkatay asa tader pokșe bhaloi hoyeche, noile ei mase bombe chutte hoto

His coming to Kolkata at this time was convenient for them. Otherwise they would have had to shoot off to Bombay.

We have a perfect equational relationship in the first sentence, which can be rendered with a zero verb and negated with noy:

tãr kolkatay asa tader pokșe bhalo (noy)

His coming to Kolkata is (not) convenient for them.

The second sentence, starting with noile is, however, not concerned with this equation, only with the consequences of his whereabouts. noile has lost its verbal character and become a coordinating conjunction meaning 'otherwise'. I take this as sufficient grounds to claim (see p. 248) that noile is no longer, either syntactically or semantically, used as the conditional participle of the verb no-.

—Perfective participle

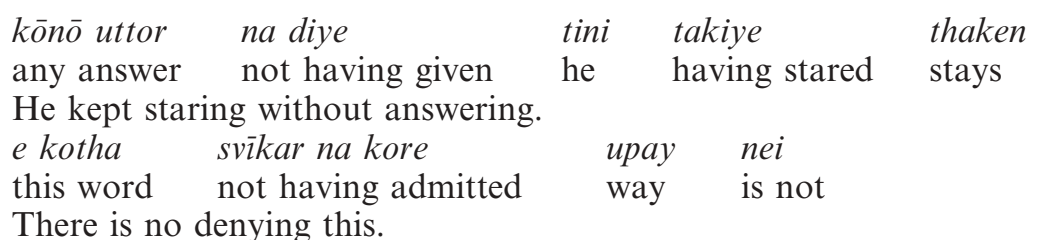


The perfective participle is, of course, the main candidate for sentence-internal negation, simply because it is the most common non-finite form. Negated perfective participles can, as in (70), often be translated with 'without' when we are looking at a sequence of events, but we need to have a closer look at the catchment area of the sentence-final negative particle. I was surprised to find the following interpretation in Clinton Seely's Intermediate Bengali (p. 306). He interprets the sentence

sekhane giye tar songe dekha korlam na
there having gone with him seeing I did not
*I didn't go there and I didn't meet her,

but accepts a separation of the two verb forms in:

$\begin{array}{llll}\text { sekhane giyeo } & \text { tar songe dekha } & \text { korlam na } \\ \text { there although having gone } & \text { with him seeing I did not as } & \text { I } \\ \text { I went but didn't meet her. } & & & \end{array}$

I can only assume that this is a straightforward mistake. The concessive $\bar{o}$ in the second sentence adds a semantic nuance but it cannot change the truth conditions of the sentence. In both sentences the act of going is not subject to the negation. The interpretation of these sentences may have been influenced by mixed compound verb structures such as niye yasya, bhule yaōya, rekhe yasya, whose internal set-up is very different to that of two sequential but separate verbs. In

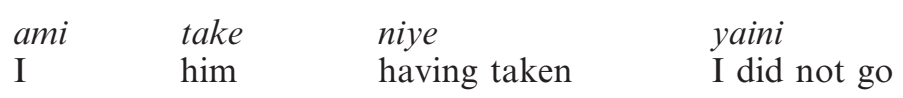

we cannot accurately guess at the real events without more information. In most cases the sentences will mean: 'I went but I didn't take him with me', which means that the sentence-final negation affects the first, but not the second of the two verbs. The more usual way of stressing the fact that the visit happened without him would be to say:

$\begin{array}{llll}\text { ami } & \text { take } & \text { rekhe } & \text { giyechi } \\ \text { I } & \text { him } & \text { having left } & \text { I went }\end{array}$

but the structure with niye yaōya is perfectly acceptable. The reason for this somewhat unorthodox state of affairs is quite simply the fact that these compounds are in a constant process of semantic bleaching and the finite verb yā̄ya 'go' can at times be an almost meaningless attachment to the main verb neōya, as it is in the compound bhule yaōya 'forget', where in most cases no 'going' takes place at all. But the situation is quite different where two consecutive actions or events are described. Since every perfective participle is capable of having its own negative particle, there is no reason to assume that a sentence-final negation extends to preceding verbal actions and I have seen no evidence of it.

-Infinitive

(72) tader songe sob somoy jhogra na korte para yay na with them always not to quarrel be able does not go It is impossible not to quarrel with them all the time.

(73) se din theke onuradhar songe kotha na bolte arombho korechilen from that day with Anuradha not to speak he began From that day onwards he started not speaking to Anuradha. 
In both of these sentences we have conjunct verbs, a noun-verb combination which is negated. This is no coincidence. Combinations of a simple verb infinitive and a following verb like para 'be able to' cāoya 'want', yas̄ya 'go', deōya 'allow' are much less likely to have a negated infinitive, e.g. ? ami take na yete dilam 'I allowed him not to go'. This is due to the semantic awkwardness of such structures more than to a syntactic consideration, and Bengali is more likely to reformulate the concept in a positive sentence, e.g. ami take thakte dilam 'I allowed him to stay'. An infinitive followed by another verb often functions as the object of this verb, the two verb forms represent one concept and this is why internal negation is rare but syntactically quite possible, particularly in negative sentences:

se take bhat na khete deyni.

She didn't allow him not to eat.

\section{Conclusion}

Linguistic phenomena like negation do not occur in isolation. Perhaps this is one reason why Bengali linguists have been somewhat negligent of this feature - it simply does not occur to them to separate negatives from the rest of the language. Every occurrence of a negative rubs shoulders with features like tense, syntactic hierarchy, the status of a verb form, case issues and word order; and at every step of the analysis one has to avoid getting sucked into the uncertain quagmire of other grammatical issues. Separating out the grammatical feature of negation, as I have done here, can be seen as an artificial exercise, an isolation of only one piece of the puzzle, but a close observation of one area gives us not only a focus but a firmer starting point for these other issues and a much better understanding of which questions need to be asked. As a result of this analysis of negation patterns, we can identify the following areas for further research:

- case use;

- tense use;

- syntactic subordination;

- the overlap of verbs of being in Bengali.

In the following areas some progress has been achieved. We have seen:

- the uses of nei and no- and a clearer dividing line between the two uses;

- the semantic range and tense use of the negative particle $n i$;

- a classification of noile as a lexical conjunction;

- the flexibility gained by internal negation;

- a new way of looking at subordination in Bengali.

REFERENCES

Primary literature-Journals

Bangla Journal Vol 4, 1-2, Toronto, April-August 2002

Vol 5, 1, Toronto, December 2004

Kali o kolom (Ink and Pen), Vol. 7, Dhaka, August 2004

Desh, Kolkata, February 2005

Fiction

Ahmed, Humayun. 1991. Ekjon mayaboti. Dhaka: Noroj Kitabistan.

Bandopadhyay, Atin. 1987. Ekti joler rekha. Kolkata: Pratibhash.

Choudhuri, Abdul Rouf. 2003. Pordeshe porbasi, Inglyander dinguli. Dhaka: Pathok Shomabesh Books. 
Debi, Moytreyi. 1986. Bidhi o bidhata. Kolkata: Praima Publications.

Debsen, Nobonita. 1996. Sita theke shuru, Kolkata: Anondo Publishers.

Haq, Hassan Azizul. 1973. Jibon ghoshe agun. Dhaka: Khan Brothers.

Haydar, Rashid. 1988. Dhaka: Mabuhai Aksar.

Hossein, Selina. 1987. Nirontor ghontadhvoni. Dhaka: Ahmed Publishing House.

Majumdar, Samaresh. 1998. Daybondhon. Kolkata: Anondo Publishers.

Ray, Praphullo. 1997. Otol joler dike. Kolkata: Dey's Publishing.

_. 1981. Akaser nice manush. Kolkata: Dey's Publishing.

\section{Non-fiction}

Poscimbanga Bangla Academy. 1993. Prosongo banglabhasha (essays).

Ara, Begum Jahan. 2005. Bangla bhasha prosongo. Dhaka: Hemi Books.

Murshid, Ghulam. 1992. Kalantore bangla godyo. Kolkata: Ananda Publishers.

\section{Secondary literature}

Anderson, James Drummond (the elder). 1920. A Manual of the Bengali Language. Cambridge (reprint, 1962).

Bangla Academy. 1993. Prosongo Banglabhasha (essays). Kolkata: Poscimbanga Bangla Academy.

Chatterji, Suniti Kumar. 1926. The Origin and Development of the Bengali Language. Kolkata: Calcutta University Press.

Dakshi, Alibha. 1995. Learning Bengali, A Self-Tutor on a Phonetic Basis. Kolkata: Subarnarelcha.

Islam, Rafiqul. 2001. Bangla byakoron somiksa. Dhaka: Globe Library.

Milne, W. S. 1913. A Practical Bengali Grammar. Kolkata

Muhammad, Qazi Din. 1963. Some Syntactic Structures of Bengali in PL (Pakistani Linguistics). 1969. Bangla Kryiapod. Dhaka: Bangla Academy Potrika.

Ramchand, Gillian. 2001. 'Two types of negation in Bengali' (unpublished).

Sarkar, Pabitra. 1998. Poket Bangla Byakoron. Kolkata: Ajkal Publishers.

Seely, Clinton B. 2002. Intermediate Bengali. Munich: Lincom Europa.

Smith, W.L. 1997. Bengali Reference Grammar. Stockholm: Association of Oriental Studies.

Thompson, Hanne-Ruth (PhD) 'Toward a definitive grammar of Bengali: a practical study and critique of research or selected grammatical structures', SOAS, 2003. 